\title{
GENERALIZATION OF SOME THEOREMS ON CLASSES OF NUMERICAL SEQUENCES
}

\author{
JóZSEF NÉMETH
}

Abstract. The theorem proved here is a generalization of some earlier results due to L. Leindler and to the present author regarding embedding relations among classes of Fourier coefficients.

Mathematics subject classification (2000): 26D15, 42A05, 42A10.

Key words and phrases: inequalities, embedding relations, Fourier coefficients.

\section{REFERENCES}

[1] R. P. BOAS JR., Integrability theorems for trigonometric transforms, Springer-Verlag, Ergebnisse 38, Berlin, 1967.

[2] G. A. Fomin, A class of trigonometric series, Mat. Zametki 23 (1978), 213-222.

[3] J. W. GARRETt AND Č. V. StAnOJEVIČ, Necessary and sufficient conditions for $L^{1}$ convergence of trigonometric series, Proc. Amer. Math. Soc. 60 (1976), 68-71.

[4] J. W. GARRETT, C. S. REES AND Č. V. STANOJEVIČ, L $L^{1}$-convergence of Fourier series with bounded variation, Proc. Amer. Math. Soc. 80 (1980), 423-430.

[5] A. N. Kolmogorov, Sur l'ordre de grandeur des coefficients de la série de Fourier-Lebesgue, Bull. Acad. Polon. Sci. (A), Sci. Math. (1923), 83-86.

[6] L. LEINDLER, On the converses of inequality of Hardy and Littlewood, Acta Sci. Math. (Szeged) 58 (1993), 191-196.

[7] L. LEINDLER AND J. NÉMETH, On the connection between quasi-monotonic and quasi geometrical sequences with application to integrability theorems for power series, Acta Math. Hungar. 68 (1-2) (1995), 7-19.

[8] L. LEINDLER, On the equivalence of classes of Fourier coefficients, Math. Inequal. Appl. 3 (2000), 45-50.

[9] L. LEINDLER, A note on some classes of real sequences, Math. Inequal. Appl. 4 (2001), 53-58.

[10] L. LeINDLER, Classes of numerical sequences, Math. Inequal. Appl. 4(2001), 515-526.

[11] M. MATElJEVIČ AND M. PAVLOVIČ, $L^{p}$-behavior of power series with positive coefficients and Hardy spaces, Proc. Amer. Math. Soc. 87 (1983), 309-316.

[12] S. M. MAZHAR, On generalized quasi-convex sequence and its application, Indian J. Pure and Appl. Math. 8 (1977), 784-790.

[13] J. NÉMETH, A note on two theorems of Leindler, Math. Inequal. Appl., 5 (2002), 225-233.

[14] S. SIDON, Hinreichende Bedingungen für den Fourier-character einer trigonometrischen Reihe, J. London Math. Soc. 14 (1939), 158-160.

[15] N. Singh AND K. M. Sharma, Integrability of trigonometric series, J. Indian Math. Soc. 49 (1985), 31-38.

[16] Č. V. Stanojevič, Classes of $L^{1}$-convergence of Fourier-Stieltjes series, Proc. Amer. Math. Soc. 82 (1981), 209-215.

[17] Č. V. Stanojevič And V. B. StanojeviČ, Generalizations of the Sidon-Telyakovskil theorem, Proc. Amer. Math. Soc. 101 (1987), 679-684.

[18] S. A. TELYAKOVSKIǏ, On a sufficient condition of Sidon for integrability of trigonometric series, Mat. Zametki (Russian) 14 (1973), 317-328. 
[19] Ž. TomovsKI, An application of the Hausdorff-Young inequality, Math. Inequal. Appl. 1 (1998), $527-532$.

[20] Ž. TomovsKI, A note on some classes of Fourier coefficients, Math. Inequal. Appl. 2 (1999), 15-18.

[21] S. Z. A. ZENEI, Integrability of trigonometric series, Tamkang J. Math. 21 (1990), 295-301. 